\title{
Zonas úmidas na planície costeira do rio Itapicuru, litoral norte do estado da Bahia, Brasil: classificação e controles ambientais *
}

\author{
Wetlands on Itapicuru River coastal plain, Northern littoral of the state of Babia, \\ Brazil: classification and environmental controls
}

\author{
Geana Sousa Soares ${ }^{\circledR, 1}$, José Maria Landim Dominguez ${ }^{2}$
}

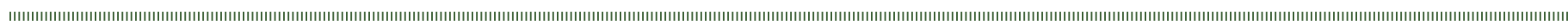

\section{RESUMO}

As zonas úmidas presentes na planície costeira do rio Itapicuru são as mais expressivas do litoral Norte do estado da Bahia. A origem e evolução das zonas úmidas do litoral Norte da Bahia estão intimamente associadas às variaçóes do nível do mar durante o Quaternário. $\mathrm{Na}$ costa do Brasil, o nível relativo do mar desceu cerca de 3-4m durante os últimos 5.600 anos AP. As lagunas e estuários formados durante o máximo Transgressivo (120.000 anos AP), evoluíram para pântanos de água doce, em decorrência do abaixamento do nível do mar durante os últimos milhares de anos. As zonas úmidas ocorrem principalmente nas terras baixas separando os terraços marinhos holocênicos e pleistocênicos e nos vales de rios e riachos que não foram completamente preenchidos por sedimentos fluviais.

Este trabalho tem como objetivo estabelecer a classificação das úmidas presentes na planície costeira do rio Itapicuru com o recurso a critérios hidrogeomorfológicos.Os termos tais como depressional com alimentação por água subterrânea, franja mareal e outros que designam classes ou tipos hidrogeomorfológicos de zonas úmidas, conferindo informaçóes úteis sobre a estrutura e funcionamento do ecossistema, e também sobre a significância no desempenho dos serviços do ecossistema e risco potencial de perda desses serviços para a integridade da paisagem. A racionalização da abordagem hidrogeomorfológica é facilitadora porque os principais tipos de zonas úmidas são fundamentalmente diferenciados por parâmetros relacionados ao desenvolvimento da topografia e a manutenção da água, embora não deixem de ser considerados os fatores bióticos destes ecossistemas naturais.

Palavras-chaves: zonas úmidas, serviços de zonas úmidas, classificação hidrogeomorfológica.

\section{ABSTRACT}

The wetlands of the Itapicuru river coastal plain are the most important of all the Northern littoral of the state of Bahia. The origin and evolution of these wetlands are intrinsically related to the Quaternary sea level changes. Along the coastline of Brazil sea level has dropped 3 to $4 m$ during the last 5.600 years BP. Estuaries and lagoons formed during the maximum of the Holocene transgression progressively evolved to freshwater wetland as a result of this drop in sea level. Nowadays the wetlands occupy the low lying areas separating Pleistocene and Holocene sandy terraces, and the bottom of valleys not completely inflled with fluvial sediments. This study used an existing GIS database, complementedby fieldwork, to classify the Itapicuru coastal plain wetlands, to establish its environmental controls and to evaluate the environmental services provided by these wetlands. The wetlands were classified using their hydrogeomorphic attributes. Terms such as depressional fed groundwater, tidal fringe among others incorporate useful information concerning the structure and functioning of the wetland ecosystem including their

@-Autor correspondente: geana@ufba.br

1 - Universidade Federal da Bahia, Instituto de Geociências, Salvador, BA, Brasil

2 - Universidade Federal da Bahia, Departamento de Geologia, Salvador, BA, Brasil 
significance in providing environmental services. The rationale behind the hydrogeomorphic approach is that the major types of wetlands can be fundamentally differentiated by parameters related to topography and water retention capacity. The classification presented herein has two immediate repercussions. Firstly it provides a framework for data collection, not only to organize existing data but also in the planning of future investigations. Secondly, and may be most important, this classification allows governmental organizations to establish goals for the creation of specific legislation for biological conservation on these areas, since the classification used is based upon the hydrogeomorphic attributes to differentiate wetland classes.

Keywords: wetlands, wetland's services, hydrogeomorphic classification.

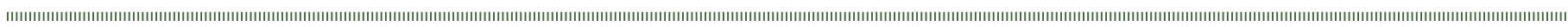

\section{INTRODUÇÃO}

Apesar de o Brasil ser signatário da Convenção de Ramsar, ainda não existem esquemas de classificação de zonas úmidas amplamente utilizados no país. Um dos poucos trabalhos neste sentido é o de Diegues (1990), que desenvolveu o primeiro inventário de zonas úmidas no Brasil. Seu estudo de caráter interdisciplinar reconheceu a importância destes ecossistemas e descreveu alguns tipos de ecossistemas aquáticos brasileiros.

No Brasil, existe uma multiplicidade de terminologias utilizadas localmente ou regionalmente para descrever as zonas úmidas. Este aspecto talvez tenha constituído um dos principais obstáculos para o estabelecimento de critérios coerentes de classificação destes sistemas. $\mathrm{O}$ conceito de Maltby (2004) utilizado neste trabalho, enfatiza a ecologia das zonas úmidas: "zonas úmidas são ecossistemas heterogêneos, mas distintos nos quais funçóes ecológicas, biogeoquímicas e hidrológicas especiais surgem a partir de características da água, como fontes dominantes e particulares, da química e da periodicidade da inundação ou saturação. Elas ocorrem em variadas paisagens e podem suportar água lenta rasa (< $2 \mathrm{~m}$ ) permanente ou temporária. Elas têm solos, substratos e biota, adaptados a inundação e/ou saturação e associados a condições de restrita aeração".

As zonas úmidas presentes na zona costeira têm seu desenvolvimento condicionado por fatores que, segundo Dalton (1999), incluem, nas regiôes tropicais: (1) os climas úmidos e super-úmidos; (2) os setores costeiros abrigados (baías, enseadas, deltas e complexos lagunares); (3) os baixos cursos fluviais principalmente meandrantes, caracterizados por sedimentos argilosos coesos e baixas declividades; e (4) as regióes com expressiva drenagem continental devido a elevados teores de nutrientes e de sedimentos.

O principal aspecto para o desenvolvimento de qualquer esquema de classificação é o conhecimento das características estruturais e funcionais do ecossistema que podem ser utilizadas para agrupar e/ou segregar, assim como sistematizar as diferentes feiçôes naturais. Cowardin et al. (1979) agruparam as zonas úmidas e ambientes aquáticos associados, em cinco sistemas: palustres, ripários, estuarinos, marinhos e lacustres. Estes sistemas constituem diferentes unidades fisiográficas da paisagem, que apesar da fisionomia aparentemente uniforme, exibem elementos vegetativos de ocorrência exclusiva, como também aqueles presentes em mais de um sistema. Para Ehrenfeld (2000), uma determinada classe de zona úmida é usualmente definida, pela composição da comunidade vegetal em associação com a hidrogeomorfologia, por exemplo, o domínio de uma zona úmida pode ser definido como uma área representada por uma depressão, com sedimentos minerais, com um dossel de árvores de grande porte ou com vegetação arbustiva densa.

Outras classificaçóes de zonas úmidas se baseiam em características relacionadas à qualidade da água (Clausen et al., 2006).

A classificação de Ramsar reconhece três grupos de zonas úmidas: marinhas e costeiras, continentais e artificiais (Peck, 1999). São ainda consideradas as unidades fisiográficas (e.g., fluvial ou palustre), a permanência da água (e.g., permanente, sazonal ou intermitente), os solos, os substratos e a vegetação. Deste modo podem ser distinguidos 35 tipos de zonas úmidas, 11 dos quais pertencentes ao grupo de zonas úmidas 'marinhas e costeiras'. Entretanto a classificação de Ramsar não utiliza termos que denotem ou indiquem características hidrogeomorfológicas para cada tipo de zona úmida.

As zonas úmidas têm sido investigadas também sob o ponto de vistageomorfológico por diversos autores (Whittecar \& Daniels, 1999; Pasternack et al. 2000; Merkey, 2006; Whigham et al. 2007). Classificaçóes hidrogeomorfológicas são consideradas como aquelas que oferecem uma boa linha de base, para distinguir os variados tipos de zonas úmidas, sua distribuição, vulnerabilidade e serviços do ecossistema, pois utilizam parâmetros fáceis de serem reconhecidos, o que evitam confusóes durante a sistematização dos atributos.

A classificação de Brinson (1993) utiliza a hidrogeomorfologia. Termos tais como fluviais, depressionais, franjas mareais e outros que designam classes ou tipos hidrogeomorfológicos de zonas úmidas, acrescentam informaçóes úteis sobre a estrutura e o funcionamento do ecossistema, inclusive sobre a significância de serviços associados a cada classe. O princípio básico da abordagem hidrogeomorfológica, reside no fato que os principais tipos de zonas úmidas são fundamentalmente diferenciados por parâmetros relacionados ao desenvolvimento da topografia e à retenção da água. A geomorfologia determina o tamanho, a forma e a profundidade de uma zona úmida. A hidrologia é a principal característica, que distingue o habitat de zona úmida de um habitat terrestre. Respostas biológicas distintas estão associadas a diferentes profundidades de lâminas d'água, suas características hidrodinâmicas e salinidades.

Mais de $50 \%$ das zonas úmidas do mundo foram destruídas durante o século passado, ignorando sua importância em oferecerem uma gama de serviços que contribuem para o bem-estar humano, como fornecimento de peixes e fibras, suprimento e purificação de água, regulação climática, regulação de inundações, proteção da zona costeira, oportunidade de recreação, e também de turismo (MEA, 2005). Sobre as causas destas perdas, Gilvear \& McIness (1994) consideraram que muitas das ameaças 
às zonas úmidas são de natureza hidrológica: abstração de água subterrânea, regulação nos fluxos dos rios, drenagens de terrenos e poluição da água.

As zonas úmidas associadas às águas doces e salobras da zona costeira brasileira têm sofrido uma grande pressão por atividades humanas, que causam interferências e modificam sua estrutura, a exemplo das "perenizaçóes" e das modificaçóes no seu entorno. A maior parte destas pressões está associada à incorporação imobiliária e à construção de grandes 'resorts' voltados para o turismo em larga escala. Isto ocorre num momento em que a importância das zonas úmidas, tem sido demonstrada, principalmente em decorrência da perspectiva de aquecimento global, que tende a aumentar a perda e degradação destas zonas e espécies associadas e a aumentar a incidência de doenças transmitidas por vetores (como a dengue) e as transmitidas pela água (como a cólera) em muitas regióes. Em países pobres, em particular, onde soluçoóes tecnológicas não estão prontamente disponíveis a demanda pelos serviços desempenhados pelas zonas úmidas (e.g., desnitrificação e proteção contra inundaçóes e tempestades), certamente aumentará nas próximas décadas (MEA, 2005). Isso tende a reduzir a capacidade dessas áreas em mitigar impactos, o que resulta na redução dos benefícios que as zonas úmidas trazem ao homem.

Insere-se, neste contexto, o Litoral Norte do Estado da Bahia, uma regiāo onde existem grandes incentivos governamentais para ocupação por parte de empreendimentos turísticos de larga escala, com as zonas úmidas sendo perenizadas para a criação de espelhos de água para fins paisagísticos ou de recreação, quando não são simplesmente seccionadas pela construção de estradas, acarretando em alteraçóes na estrutura física, na hidrologia e conseqüentemente na composição biótica. Esta é uma regiāo bem cartografada, onde já foram realizadas diversas investigaçóes do ponto de vista geológico-geomorfológico, que oferecem uma gama de informações, que facilita a aplicação de esquemas de classificação hidrogeomorfológica para as zonas úmidas.

A origem e evolução das zonas úmidas do litoral Norte da Bahia estão intimamente associadas às variaçôes do nível do mar durante o Quaternário (Martin et al., 1980; Suguio et al., 1985; Dominguez et al., 1990; Leâo \& Dominguez, 2000). Na costa do Brasil, o nível relativo do mar desceu cerca de 3-4m durante os últimos 5.600 anos AP. As lagunas e estuários formados durante o máximo Transgressivo (120.000 anos AP), evoluíram para pântanos de água doce, em decorrência do abaixamento do nível do mar durante os últimos milhares de anos (Dominguez et al., 1990). As zonas úmidas ocorrem principalmente nas terras baixas separando os terraços marinhos holocênicos e pleistocênicos e nos vales de rios e riachos, que não foram completamente preenchidos por sedimentos fluviais (Dominguez et al., 1990).

No litoral Norte do estado da Bahia, as mais expressivas zonas úmidas estão localizadas na planície costeira do rio Itapicuru, aspecto este que definiu a sua escolha para a presente investigação. Nesta região, são encontrados tipos de zonas úmidas representativos de parte o litoral Norte do estado da Bahia.

Neste artigo, é apresentada uma tentativa de aplicação da classificaçấo hidrogeomorfológica para as zonas úmidas presentes na planície costeira do rio Itapicuru. A ênfase dada neste trabalho para os fatores abióticos, de modo algum tem a intenção de ignorar ou trivializar a importância que os organismos desempenham na estrutura e função dos ecossistemas de zonas úmidas. Alguns estudos têm demonstrado a validade desta classificação também, em áreas da Ásia (Finlayson et al., 2002), da Europa (Maltby, 2004), e especificamente na África do Sul (Ewart-Smith et al., 2006) e na Escócia (Martin et al., 2007). Exemplos de sua construção e aplicação também são documentados por Wardrop et al., 2007, Whigham et al., 2007, Shaffer et al., 2007 e Franklin et al., 2008.

Este estudo utilizou uma base de dados existente, a qual quando integrada aos dados coletados durante os trabalhos de campo, permitiu não só classificar as zonas úmidas, como avaliar os controles ambientais responsáveis por sua distribuição e estrutura.

A delimitação das classes de zonas úmidas permitiu a avaliação da significância ecológica das características hidrogeomorfológicas, no desempenho de serviços e o risco de perda da zona úmida (Sutter et al., 1999). Serviços do ecossistema são os resultados de processos físicos, químicos e biológicos que ocorrem independentemente de qualquer benefício, real ou suposto, para a sociedade humana (UNESCO, 1998). Para começar a entender a significância dos serviços desempenhados por zonas úmidas, a premissa inicial desta abordagem é que estes serviços não são produtos de um lugar particular da zona úmida, mas das relaçóes entre um lugar particular e seus arredores (Sutter et al., 1999). A ocorrência e manutenção de zonas úmidas e dos processos que nelas ocorrem, são resultados da larga escala e das características de longo prazo da zona costeira e regimes climáticos da região, além de outros processos locais (Dominguez et al., 1996). Estes serviços são observados mais corretamente como serviços do complexo, mais do que serviços de zonas úmidas individuais (Sutter et al., 1999).

A classificação das zonas úmidas aqui realizada tem duas repercussóes imediatas. Primeiramente estabelece uma estrutura de coleção de dados, tanto para organizar estes dados quanto para apontar onde dados adicionais deverão ser coletados em futuras investigações. A segunda repercussão e certamente a mais importante, é que esta classificação permitirá aos órgãos ambientais estabelecer metas para criação de diretrizes e legislação específica, para a conservação da biodiversidade nestas áreas.

Esta pesquisa teve assim como objetivo classificar as zonas úmidas na planície costeira do rio Itapicuru, no norte da Bahia, permitindo a diferenciação dos principais controles ambientais inerentes a cada classe. Objetivos específicos incluíram: (i) classificar hidrogeomorfologicamente as zonas úmidas da área de estudo; (ii) através das características hidrogeomorfológicas de cada classe, avaliar a significância dos serviços desempenhados por zonas úmidas e o risco potencial de perda destes serviços para a paisagem onde elas estáo inseridas.

\section{2. ÁREA DE ESTUDO}

A área estudada está situada no litoral Norte do estado da Bahia, no município de Conde (Fig. 1). A planície costeira 
do rio Itapicuru compreende em termos de superfície aproximadamente $944,06 \mathrm{~km}^{2}$ (Esquivel, 2006).

A zona costeira Nordeste do estado da Bahia, situa-se na faixa intertropical, possui um clima úmido a subúmido e seco a subúmido, apresentando durante os meses de veráo os períodos de mais alta temperatura (aproximadamente entre $27-31^{\circ} \mathrm{C}$ ), que coincidem com os períodos de pouca chuva (setembro a fevereiro). Os índices pluviométricos anuais - em torno de $1600 \mathrm{~mm}$ com maiores concentraçóes nos meses de outono-inverno, devido à influência de frentesfrias mais efetivas no hemisfério Sul. Os valores de insolação são quase sempre superiores a 2000 horas anuais em toda a área, havendo um ligeiro decréscimo nos meses de outonoinverno. Os índices de umidade relativa são geralmente superiores a $80 \%$ (CEI, 1994).

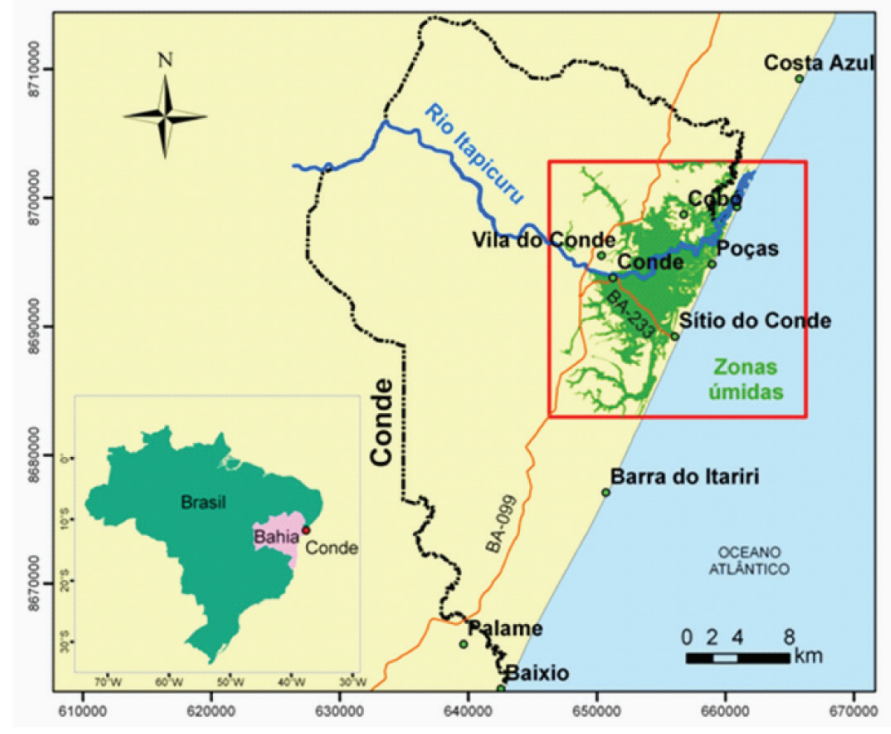

Figura 1. Localização da área de estudo.

Figure 1. Study area.

As zonas úmidas da área de estudo ocupam uma área total de $164,2 \mathrm{~km}^{2}$. Para estas zonas úmidas convergem três cursos d'água.

- OrioItapicuruquedrenaumaáreadeaproximadamente $36.168 \mathrm{~km}^{2}$.

- Associado às zonas úmidas situadas na margem esquerda do rio Itapicuru, deságua o rio Crumaí, que drena uma área de $187,8 \mathrm{~km}^{2}$.

- O rio das Pontes drenando uma área de aproximadamente $150,7 \mathrm{Km}^{2}$, corta grande parte das zonas úmidas situadas à margem direita do rio Itapicuru.

A planície costeira apresenta uma geometria triangular, caracterizada por um expressivo vale parcialmente preenchido por depósitos arenosos de origem marinha e continental, associados a diferentes níveis de mar alto, durante o Quaternário. Dentre estes depósitos destacam-se, os leques aluviais e os depósitos praiais de idade pleistocênica, associados a um nível de mar mais alto, durante o Pleistoceno (120.000 anos AP), e os depósitos praiais e de delta de cabeceira de baía, ambos de idade holocênica (Dominguez et al., 1990). Nas zonas baixas entre estes depósitos, ocorrem as zonas úmidas objeto deste estudo, que também estão presentes nos fundos de vales associados à Formação Barreiras, de idade terciária, localmente conhecidos como Tabuleiros Costeiros.

\section{MÉTODOS}

Nesta pesquisa, foi utilizado o mapa geológicogeomorfológico de Esquivel (2006), disponibilizado no formato digital e produzido na escala original de 1:25.000. Os arquivos digitais foram incorporados a um Sistema de Informações Geográficas, utilizando o software Arc Gis 9.2.

Para suplementar as informaçôes cartográficas com outras informaçôes importantes para a aplicação do esquema de classificação, incluindo dados sobre a vegetação dominante, foram feitas seis incursôes utilizando barco, carro ou a pé, nas zonas úmidas na planície costeira do rio Itapicuru. Especificamente em áreas de vegetação arbórea, as marcas do nível da água na vegetação, serviram de base para identificação da magnitude da flutuação do nível da água.

O componente geomorfológico de uma zona úmida pode ser categorizado com base nas geometrias em seção. As geometrias em seção podem ser na forma de bacias, declives e planícies. Bacias têm a área da depressão central distinta da zona litoral. Declives são áreas com gradientes que podem ser maiores que $1 \%$. Planícies são marcadas por pouco ou nenhum relevo marginal e têm limites laterais difusos. Ocorrem geralmente em interflúvios de rios e córregos.

Em relação aos atributos hidrológicos, três aspectos são importantes para o esquema de classificação: (1) as fontes de água, que podem ser simplificadas em três categorias: precipitação; fluxos superficiais e fluxos sub-superficiais; exudação de água subterrânea; (2) a hidrodinâmica, que se refere à direção de fluxo e (3) o hidroperíodo na zona úmida. Os fluxos em zonas úmidas podem ser verticais ou horizontais, uni ou bilaterais. O hidroperíodo pode variar de permanente a intermitentemente inundado ou saturado.

Os dados espaciais, disponíveis para a planície costeira do rio Itapicuru, foram utilizados para determinar três características primárias dos principais controles ambientais em zonas úmidas: (i) a geomorfologia da zona úmida; (ii) características hidrológicas da superfície, incluindo: canais, caminhos e os corpos de água parada; e (iii) os padróes de cobertura da vegetação.

De posse da espacialização destas características, foi aplicada a classificação hidrogeomorfólogica, utilizando-se a chave extraída de Smith et al. (1995) (Tabela 1).

Após a determinação das classes hidrogeomorfológicas, todos os dados obtidos foram interpretados e integrados com o uso do SIG, utilizando o software Arc Gis 9.2 . O produto final oferece assim, uma base de dados rigorosa, compreensível e nova.

Após a produçáo do mapa final, com as categorias hidrogeomorfológicas das zonas úmidas, foram selecionados os indicadores do desempenho de serviços para cada classe. Nesta etapa foi utilizada a metodologia desenvolvida por 
Tabela 1. Identificação das classes hidrogeomorfológicas de zonas úmidas.

Table 1. Identification key of hydrogeomorphic classes of wetlands.

\begin{tabular}{|c|c|c|}
\hline $\begin{array}{l}\text { NO. } \\
\text { CHAVE }\end{array}$ & HIDROGEOMORFOLOGIA CARACTERÍSTICA & $\begin{array}{c}\text { CLASSE } \\
\text { HIDROGEOMORFOLÓGICA }\end{array}$ \\
\hline 1. & Zona úmida é influenciada pela maré & 2 \\
\hline 1. & Zona úmida não é influenciada pela maré & 4 \\
\hline 2. & Salinidade $>30 \mathrm{ppt}$ & Franja mareal (euhalina) \\
\hline 2. & Salinidade $<30 \mathrm{ppt}$ & 3 \\
\hline 3. & Salinidade 5-30 ppt & Franja mareal (mixohalina) \\
\hline 3. & Salinidade $<5$ ppt & Fluvial (mareal) \\
\hline 4. & $\begin{array}{l}\text { Zona úmida é topograficamente plana e tem a precipitação como fonte de água } \\
\text { dominante }\end{array}$ & 5 \\
\hline 4. & $\begin{array}{l}\text { Zona úmida não é topograficamente plana e não tem a precipitação como fonte de água } \\
\text { dominante }\end{array}$ & 6 \\
\hline 5. & Zona úmida tem o solo mineral & Planície de solo mineral \\
\hline 5. & Zona úmida tem o solo orgânico & Planície de solo orgânico \\
\hline 6. & Zona úmidaé associada com canais, planície de inundação ou terraço & 7 \\
\hline 6. & $\begin{array}{l}\text { Zona úmidaé associada com uma depressão topográfica ou num declive topográfico ou } \\
\text { planície }\end{array}$ & 9 \\
\hline 7. & Canal é intermitente ou efêmero & Fluvial não-perene \\
\hline 7. & Canal é perene & 8 \\
\hline 8. & Canal é de $1^{\text {a }}$ ou $2^{\text {a }}$ ordem & Fluvial (de alto gradiente) \\
\hline 8. & Canal é de $3^{a}$ ordem ou maior & Fluvial (de baixo gradiente) \\
\hline 9. & Zona úmida é localizada numa depressão topográfica natural ou artificial & 10 \\
\hline 9. & Zona úmidaé localizada num declive topográfico & 13 \\
\hline 10. & $\begin{array}{l}\text { Depressão topográfica tem a profundidade de água permanente }>2 \mathrm{~m} \text { e zona úmida é } \\
\text { restrita à margem da depressão }\end{array}$ & Franja lacustre \\
\hline 10. & Depressão topográfica não tem profundidade de água permanente $>2 \mathrm{~m}$ & 11 \\
\hline 11. & $\begin{array}{l}\text { Depressão topográfica fechada sem superfície discernível de entradas e saídas de águas ou } \\
\text { outras conexões }\end{array}$ & Depressional (fechada) \\
\hline 11. & $\begin{array}{l}\text { Depressão topográfica aberta com superfície discernível de entradas e saídas de águas ou } \\
\text { outras conexões }\end{array}$ & 12 \\
\hline 12. & Fonte primária de água é a água subterrânea & Depressional (aberta, água subterrânea) \\
\hline 12. & Fonte primária de água é a precipitação ou escoamento superficial & Depressional (aberta, água de superfície) \\
\hline 13. & Fonte primária de água é a água subterrânea & Em declive \\
\hline 13. & Fonte primária de água é a precipitação & Planície de solo orgânico \\
\hline
\end{tabular}

Sutter et al. (1999) que se baseia em parâmetros como: proximidades de corpos d'água, hidroperíodo, tipo de vegetação, largura, tamanho e uso do solo nas classes de zonas úmidas, para avaliar a significância delas no desempenho de serviços associados à qualidade da água, à hidrologia e à qualidade do habitat. A significância destes três serviços foi classificada em alta, moderada ou baixa (A, $\mathrm{M}$ ou $\mathrm{B}$, respectivamente) para cada classe, assim como o risco potencial de perda destes serviços para a paisagem. Isto é importante porque utiliza um esquema funcional para avaliar a significância de serviços do ecossistema, fortemente baseados em medidas estruturais (Cole, 2006). 


\section{RESULTADOS E DISCUSSÁO}

\subsection{Classificação hidrogeomorfológica das zonas úmidas na planície costeira do rio Itapicuru}

Quatro classes/subclasses principais de zonas úmidas foram reconhecidas, sendo uma destas subdividida em dois subtipos (Tabela 2). As geometrias em seção das classes de zona úmida estão esquematizadas nas figuras 3 a 6 . A distribuição espacial das diferentes classes de zonas úmidas é mostrada na Figura 7. Exemplos das classes são mostrados nas figuras 8 a13.

As características das quatro classes e subclasses hidrogeomorfológicas reconhecidas na área de estudo estão descritas abaixo.

1) Zonas úmidas em declives por exudação de água subterrânea: ocorrem onde quebras de declividade resultam em exudação da água subterrânea, ou seja, onde o fluxo de água intercepta a superfície do terreno (Fig. 2). A saturação por exudação da água subterrânea, com fluxo unidirecional declive abaixo e a perda de água pela evapotranspiração, são as principais influências hidrológicas nas zonas úmidas em declive identificadas. A precipitação frequentemente é uma contribuição secundária na fonte de água.

$\mathrm{Na}$ área de estudo, zonas úmidas em declive por exudação da água subterrânea, são encontradas principalmente nas bordas dos terraços arenosos internos, de idade pleistocênica, quando uma quebra de declive pronunciada está presente
(Fig. 7; Fig. 11). Nestes trechos, o terreno pode apresentarse saturado de água e pode localmente apresentar nascentes. A presença deste tipo de zona úmida resulta provavelmente do fato destes depósitos arenosos apresentarem barreiras de permeabilidade, associadas a horizontes espódicos coesos, característicos dos espodossolos que se desenvolvem nesta unidade, às quais forçam a água subterrânea à exudar na quebra de declive.

A cobertura vegetal nas zonas úmidas em declive por exudação da água subterrânea, incluem espécies de macrofítas aquáticas emersas de baixo porte, com dominância de Eleocharis sp.

2) Zonas úmidas depressionais com alimentação por água subterrânea: ocorrem na planície costeira do rio Itapicuru, possuindo tanto atributos de zonas úmidas fluviais de baixo gradiente não aluviais, quanto de zonas úmidas depressionais, por causa dos fluxos laterais muito fracos e pelo fato de que, quando existem canais associados, os níveis de sedimento em suspensão nos cursos d'água são muito baixos. O fluxo de água ocorre em canais rasos, que funcionam como conduto para drenagem das zonas úmidas vizinhas (Fig. 3). Zonas úmidas depressionais ocorrem em bacias planas, onde o lençol freático aflora (i.e., contornos da elevação fechados). Estas depressóes podem ter uma combinaçáo de entrada e saída de água ou nenhuma destas, e são alagadas permanentemente de acordo com o volume de exudação das águas subterrâneas dos aquíferos do Quaternário. As

Tabela 2. Classificação das zonas úmidas costeiras associadas com rio Itapicuru.

Table 2. Classification of coastal wetlands associated with the river Itapicuru.

\begin{tabular}{|c|c|c|}
\hline \multicolumn{2}{|c|}{$\begin{array}{l}\text { Classe (baseada na condiçáo geomorfológica)/Subclasse (baseada no } \\
\text { mecanismo de transferência da água) Hidrogeomorfológicas de Zonas Úmidas }\end{array}$} & Fitofisionomia \\
\hline \multicolumn{2}{|c|}{$\begin{array}{l}\text { Zona úmida em declive por exudação da água subterrânea } \\
\text { (Groundwater slope wetland) }\end{array}$} & Herbácea de baixo porte \\
\hline \multirow{6}{*}{$\begin{array}{l}\text { Zona úmida depressional } \\
\text { alimentada por água subterrânea } \\
\text { (Groundwater depression wetland) }\end{array}$} & \multirow{4}{*}{$\begin{array}{l}\text { Zona úmida depressional alimentada por } \\
\text { água subterrânea aberta } \\
\text { (Open groundwater depression wetland) }\end{array}$} & $\begin{array}{c}\text { Aquática com folhas flutuantes, com folhas } \\
\text { submersas livres ou enraizadas e com raízes } \\
\text { flutuantes }\end{array}$ \\
\hline & & Herbácea de alto porte \\
\hline & & Herbácea de baixo porte \\
\hline & & Floresta paludosa \\
\hline & \multirow[t]{2}{*}{$\begin{array}{l}\text { Zona úmida depressional alimentada } \\
\text { por água subterrânea fechada (Closed } \\
\text { groundwater depression wetland) }\end{array}$} & $\begin{array}{c}\text { Aquática com folhas flutuantes, com folhas } \\
\text { submersas livres ou enraizadas e com raízes } \\
\text { flutuantes }\end{array}$ \\
\hline & & Herbácea de baixo porte \\
\hline \multicolumn{2}{|c|}{$\begin{array}{l}\text { Zona úmida fluvial } \\
\text { (Riverine lower perennial wetland) }\end{array}$} & Gramínea exótica \\
\hline \multicolumn{2}{|c|}{$\begin{array}{l}\text { Zona úmida franja mareal } \\
\text { (Tidal fringe wetland) }\end{array}$} & Manguezal \\
\hline
\end{tabular}




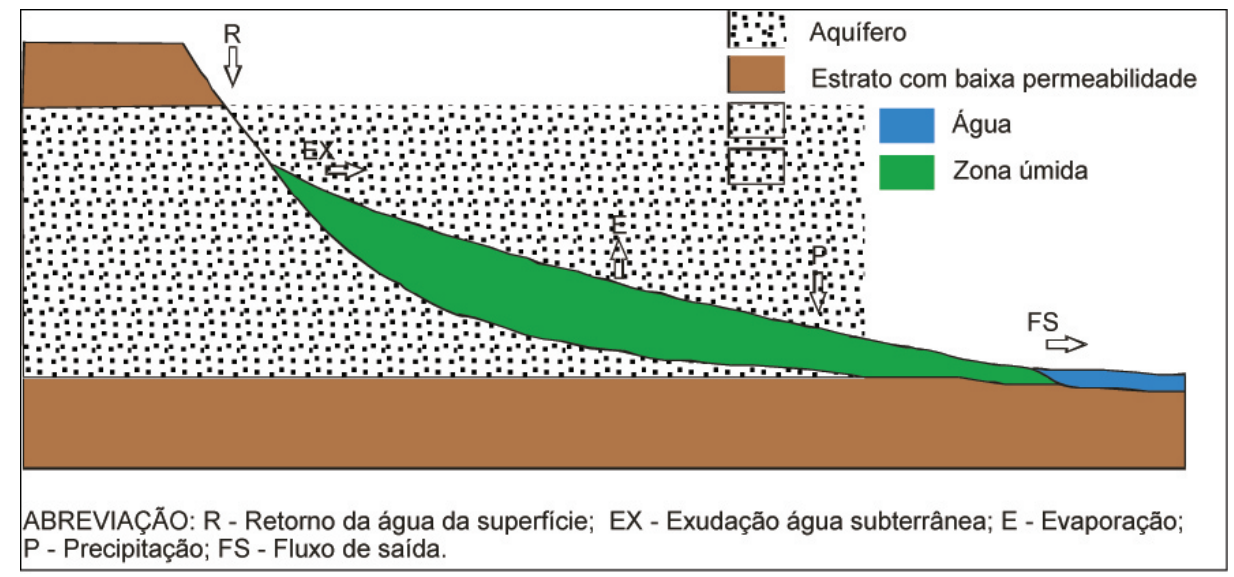

Figura 2. Seção da zona úmida em declive por exudação da água subterrânea.

Figure 2. Section view: slope wetlands groundwater-fed

flutuaçôes do nível da água predominantes são verticais e variam sobretudo sazonalmente. Zonas úmidas depressionais podem perder água por evapotranspiração, saídas de água intermitentes ou permanentes, ou recarga do lençol-freático. As águas destas depressões apresentam coloração cor-de-chá e são ácidas, como resultado da matéria orgânica dissolvida da primeira camada do solo e não excedem a profundidade de $2 \mathrm{~m}$ na estação seca. Depósitos turfosos são formados em áreas onde o nível da água é alto. A água é normalmente pobre em minerais dissolvidos principalmente quando a taxa de acumulação da matéria orgânica é maior do que a taxa de decomposição. Zonas úmidas depressionais ocorrem em bacias com "solos orgânicos" (profundidade contínua de matéria orgânica $>0,4 \mathrm{~m}$, como definido por NWWG, 1997). Normalmente estes solos apresentam depósitos constituídos por sedimentos finos, compostos por argilas e material vegetal de origem autóctone e alóctone (CPRM, 1982).

A área ocupada por esta unidade é bastante expressiva, abrangendo um total de $59,41 \mathrm{~km}^{2}$, o que representa $36,2 \%$ do total das zonas úmidas na planície do rio Itapicuru (Fig.7).

$\mathrm{Na}$ área de estudo duas subclasses podem ser encontradas:

2.1 Subtipo 1 - zonas úmidas depressionais abertas, com presença de entradas e saídas de água e uma grande área de captação, que dá suporte a feiçôes fluviais de caráter secundário. O balanço hídrico é dominado por fluxos laterais superficiais e descarga. $\mathrm{Na}$ área de estudo, ocorre no fundo dos vales entalhados na Formação Barreiras (Fig. 3), nas zonas baixas entre os terraços arenosos internos e externos (figuras 7,8 e 9) e nas zonas baixas que bordejam os pequenos cursos d'água, como os rios Crumaí e Pontes.

2.2 Subtipo 2 - zonas úmidas depressionais fechadassem entradas e saídas de água. Este tipo de zona úmida foi construída pelo vento, ocupa depressōes fechadas presentes na superfície das bacias de deflação do tipo "blow-out" associadas às dunas (Fig.4). É o tipo menos expressivo de zona úmida na planície costeira do rio Itapicuru (Fig. 7).

A vegetação dominante em áreas não florestais incluem as macrófitas aquáticas emersas Eleocharis sp., Cyperus spp. (tirrica e papirus) e Typha sp., principalmente. Uma expressiva área de floresta no subtipo 1 (Fig. 10) está presente na porção norte da planície costeira, apresentando uma vegetação extremamente variável, com ocorrências de espécies típicas de floresta paludosa, também conhecida como florestas de brejo (Ivanauskas et al., 1997) tais como Annona sp., landirana, Cecropia sp. e Calophyllum brasilienses. Nesta área existe maior influência da precipitaçáo como fonte de água da zona úmida, devido à existência de microtopografia formada por acúmulo de matéria orgânica. Em termos de abrangência espacial, as áreas de porte arbóreo com floresta paludosa ocupam um total de aproximadamente $4,93 \mathrm{~km}^{2}$, o que vem a representar cerca de $3 \%$ do total das zonas úmidas na planície costeira do rio Itapicuru. A cobertura da vegetação arbórea típica de água doce também está presente em pequenos trechos interioranos de alguns vales entalhados na Formação Barreiras também no subtipo 1.

3) Zona úmida fluvial de baixo gradiente: ocorre na planície associada a canais, neste caso o rio Itapicuru. Estudos da história evolutiva da planície costeira do rio Itapicuru (Dominguez et al., 1996) indicaram que esta zona úmida fluvial está implantada sobre depósitos de um delta de cabeceira de baía construído pelo rio durante o máximo da Última Transgressão. Esta unidade é constituída por sedimentos areno-lamosos recobertos por depósitos de canais abandonados e de diques marginais (Dominguez et al., 1996).

Este tipo de zona úmida desenvolveu-se sobre áreas com acúmulo de água na ou próximo à superfície por extensos períodos de tempo, resultando na presença de solo hídrico e vegetação higrófila, com poucas áreas de água aberta. Esta classe comumente é associada a declives menores que $0,5 \%$, e a principal característica hidrológica é o fluxo lateral a partir do extravasamento do rio (Fig. 12). Estas zonas úmidas sofrem inundaçóes com profundidades de apenas poucos centímetros (Fig. 5). Este tipo de zona úmida representa um tipo de "floodway" sem canais conectados com o rio durante fluxos normais. Esta classe de zona úmida é uma das mais extensas da planície costeira, com área total de $26,34 \mathrm{~km}^{2}$ representando $16,04 \%$ da área total ocupada pelas zonas úmidas na planície (Fig.7). 


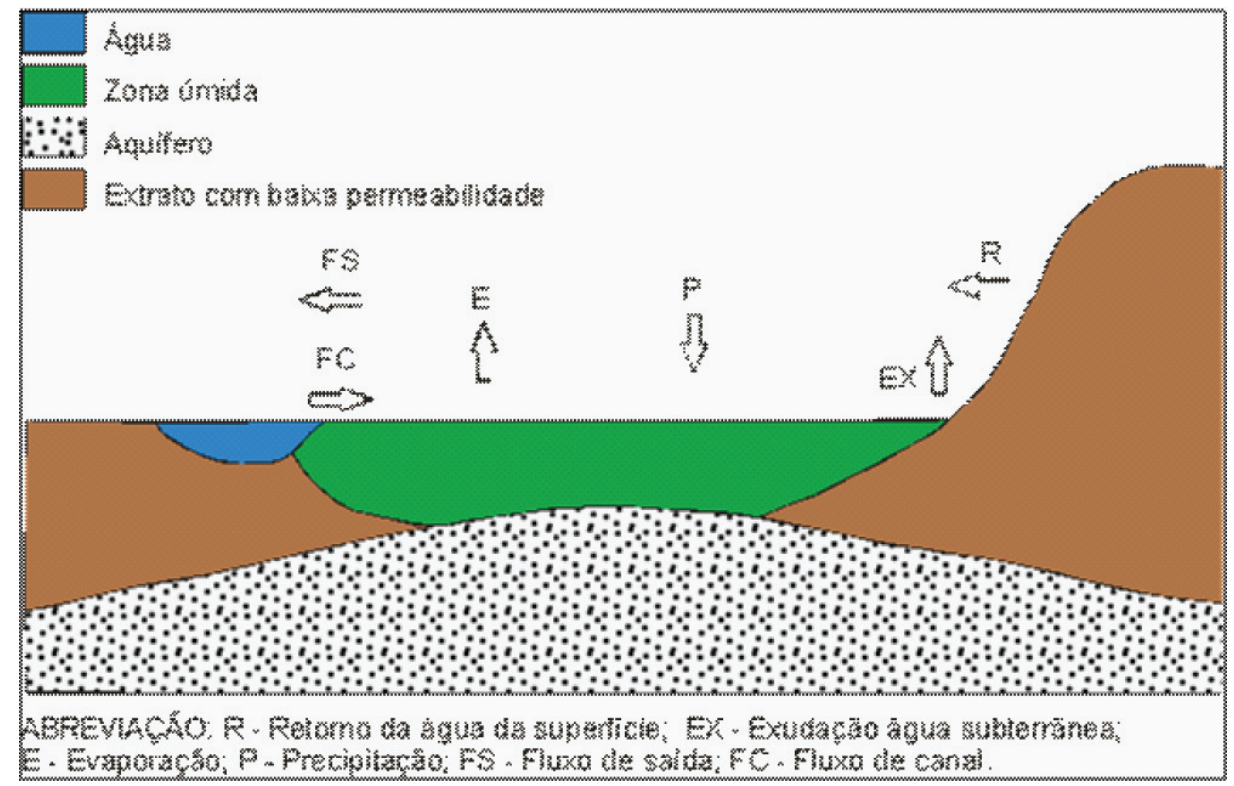

Figura 3. Seção da classe hidrogeomorfológica de zona úmida depressional alimentada por água subterrânea aberta em vales de canais.

Figure 3. Section view: open depressional wetland hydrogeomorphic class, groundwater-fed on valleys of channels.

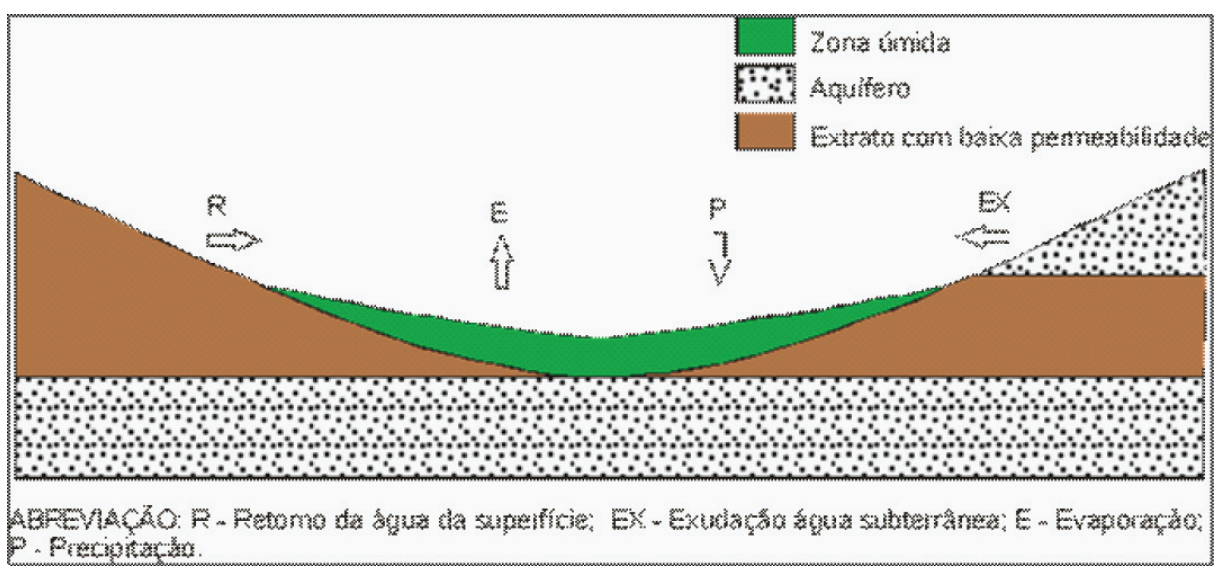

Figura 4. Seção da classe hidrogeomorfológica de zona úmida depressional fechada alimentada por água subterrânea.

Figure 4. Section view: closed depression wetland hydrogeomorphic class, groundwater-fed.

$\mathrm{O}$ rio Itapicuru extravasa anualmente, principalmente nos meses de veráo como resultado do aumento do índice pluviométrico na área de cabeceira. $\mathrm{O}$ escoamento superficial local contribui para a manutenção da saturação entre as inundaçōes principais, quando pequenas poças se desenvolvem depois das chuvas.

A cobertura da vegetação na planície de inundação é muito dinâmica e pode mudar em resposta às flutuaçôes sazonais da saturação. As espécies de plantas incluem formas aquáticas com folhas flutuantes, como a Nymphaea sp. Com folhas submersas, podendo também ser livres como a Utricularia sp., ou enraizadas como a Mayaca sp. e com raízes flutuantes, como o aguapé (Eichornia sp.) principalmente em trechos correspondentes a paleocanais. Contudo, espécies emersas, principalmente gramináceas tolerantes às inundaçóes, sobretudo a exótica Brachiara sp., domina uma extensa área da planície, principalmente no verão.

4) Zonas úmidas em franjas mareais: ocorrem em áreas costeiras e sofrem a influencia das marés. Elas fazem transição para zonas úmidas fluviais onde as correntes mareais diminuem e o fluxo do rio é a principal fonte de água. Fontes adicionais de água podem ser a água subterrânea e a precipitação. A interface entre as classes franja mareal e fluvial situa-se onde os fluxos bidirecionais dominam os fluxos unidirecionais do rio. Por serem frequentemente inundadas pelas marés, as franjas mareais raramente ficam secas por períodos significativos. Zonas 
úmidas em franjas mareais perdem água pelas mudanças das marés, pela saturação do fluxo com transbordamento para canais de marés, e pela evapotranspiração. A matéria orgânica normalmente se acumula em áreas afastadas da ação erosiva das ondas na linha de costa.

Neste tipo de zona úmida há uma predominância de argilas escuras, com presença secundária de areias e siltes de origem fluvial ou marinha, formando lamas plásticas ricas em matéria orgânica (CPRM, 1982). Apresentam uma área total de $16,54 \mathrm{~km}^{2}$; representando $10 \%$ do total das zonas úmidas na planície (Fig.7).
A cobertura da vegetação nesta classe de zona úmida em franja mareal costeira integra o ecossistema manguezal, no qual as plantas desenvolveram adaptaçóes para colonizar solos e regióes caracterizadas por elevadas salinidades, sujeitas ao fluxo e refluxo das marés (Lugo \& Snedaker, 1974), incluindo espécies emersas herbáceas halófitas, como Spartina sp. A principal comunidade dominante está associada à espécie Rhizhophora mangle, com outras espécies típicas de manguezais brasileiros como Avicennia sp. e Laguncularia sp., constituindo formaçóes florestais na desembocadura do rio Itapicuru (Fig.6; Fig.13).

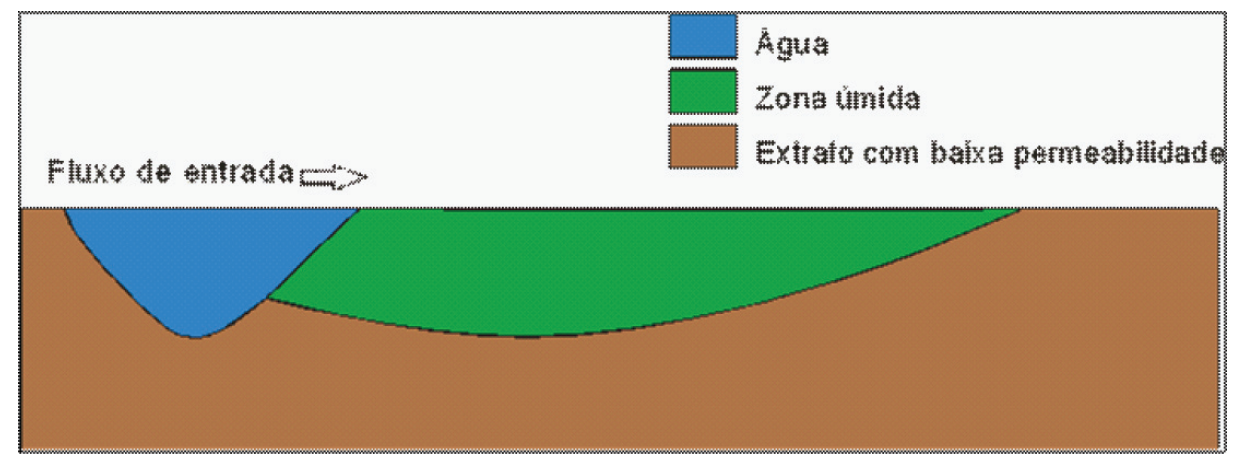

Figura 5. Seção da classe hidrogeomorfológica de zona úmida fluvial).

Figure 5. Section view: fluvial wetland hydrogeomorphic class.

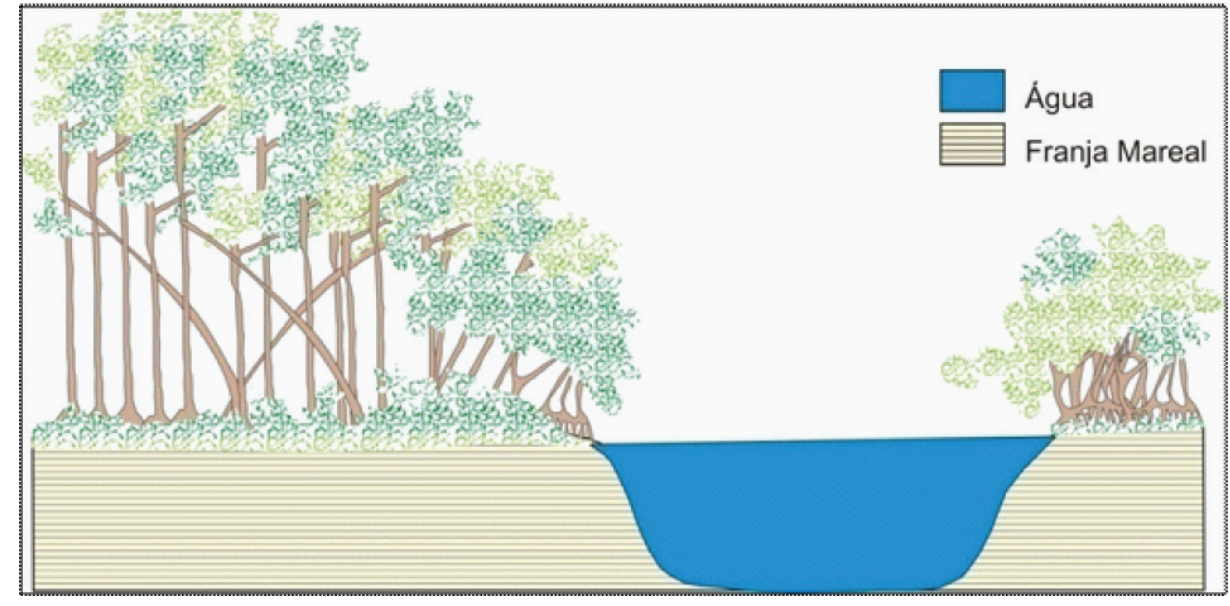

Figura 6. Zona úmida franja mareal na desembocadura do rio Itapicuru).

Figure 6. Mareal fringe wetland on Itapicuru river mouth. 


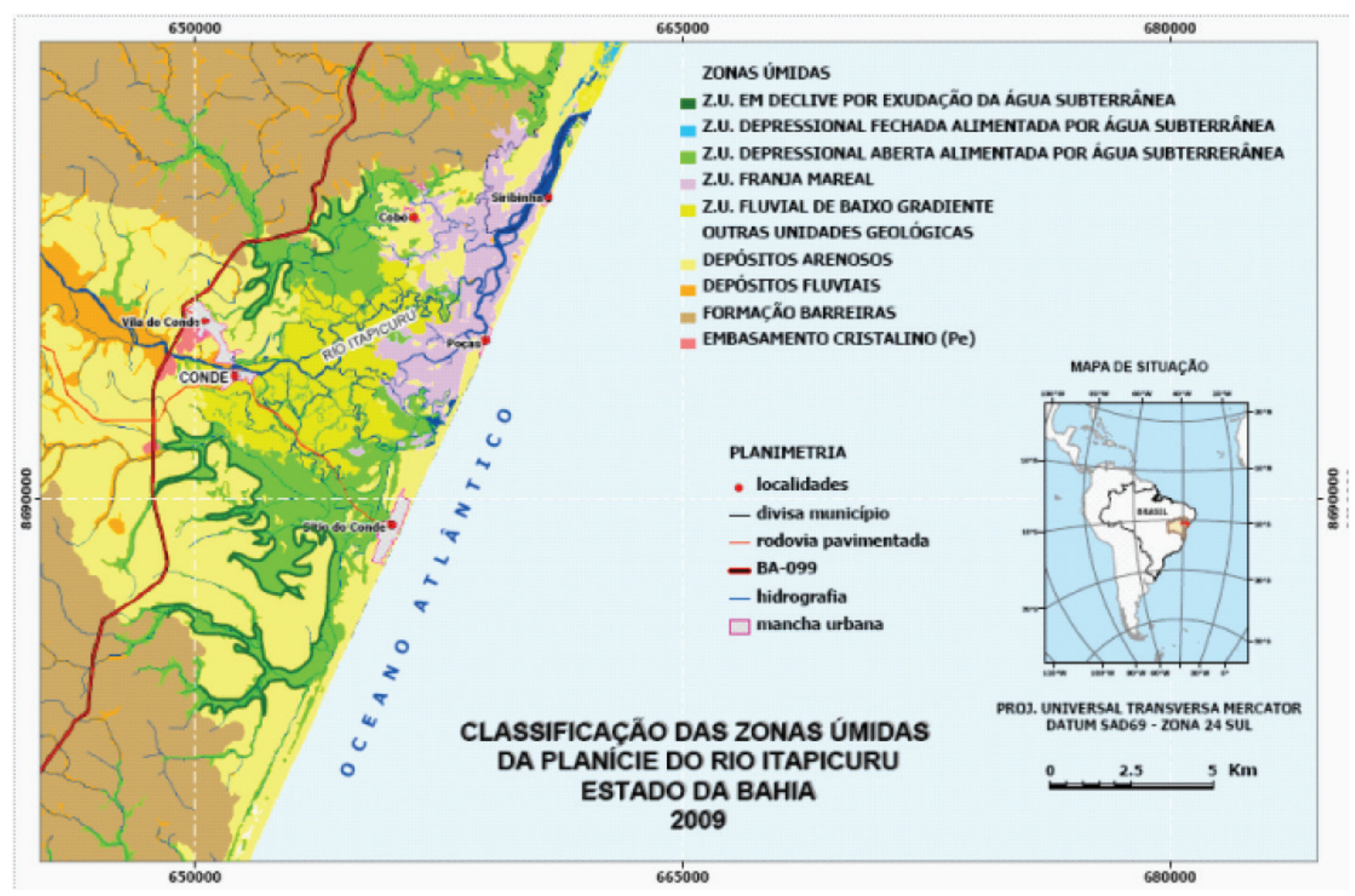

Figura 7. Mapa de classificação das zonas úmidas na planície do rio Itapicuru).

Figure 7. Map of classification of coastal wetlands on Itapicuru river.

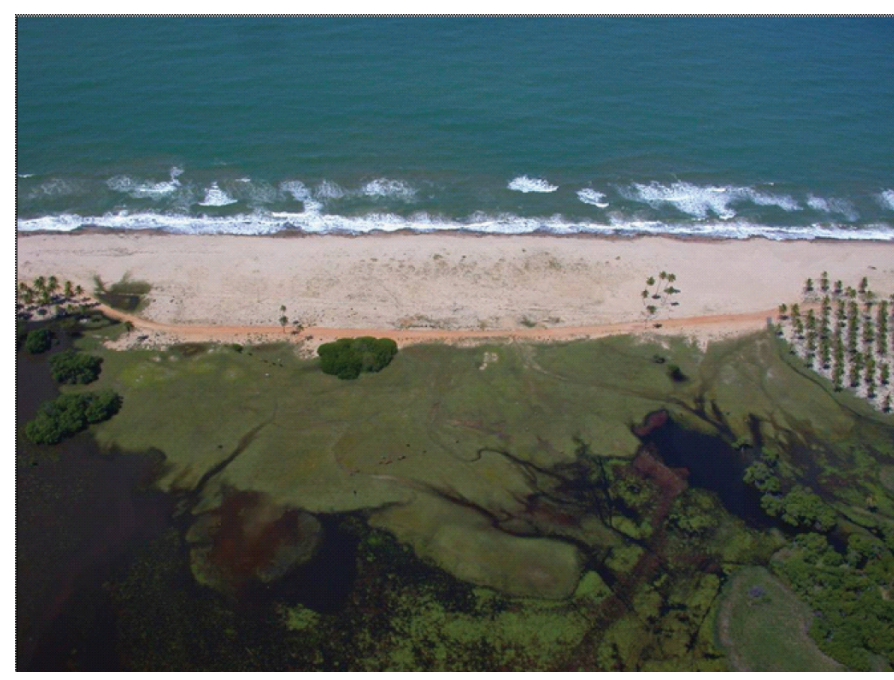

Figura 8. Zonas úmidas depressionais abertas alimentadas por água subterrânea, na localidade de Barra Nova.

Figure 8. Depressional wetlands groundwater-fed on Barra Nova locality. Foto: Dominguez 01/2007.

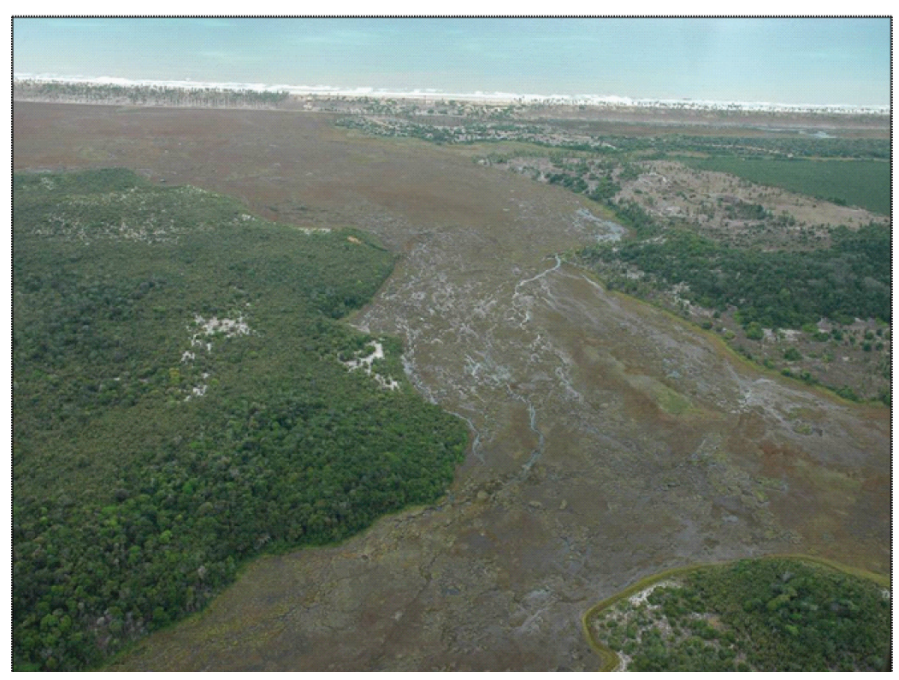

Figura 9. Zonas úmidas depressionais abertas alimentadas por água subterrânea, ao fundo a localidade de Sítio do Conde).

Figure 9. Depressional wetlands groundwater-fed on Sitio do Conde. Foto: Dominguez 01/2007. 


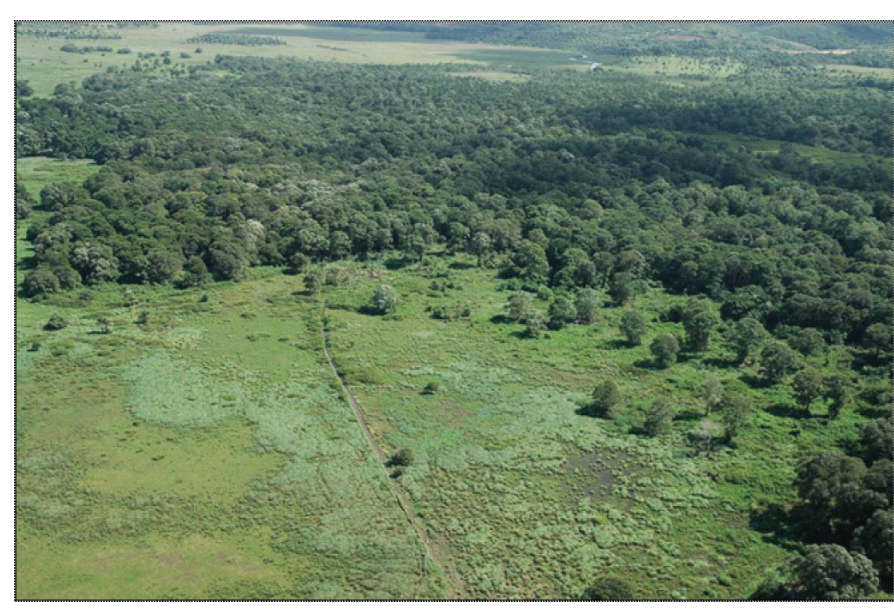

Figura 10. Zona úmida depressional aberta com alimentação da água subterrânea, com vegetação arbórea.

Figure 10. Depressional wetlands groundwater-fed with arboreo vegetation.

Foto: Dominguez 01/2007.

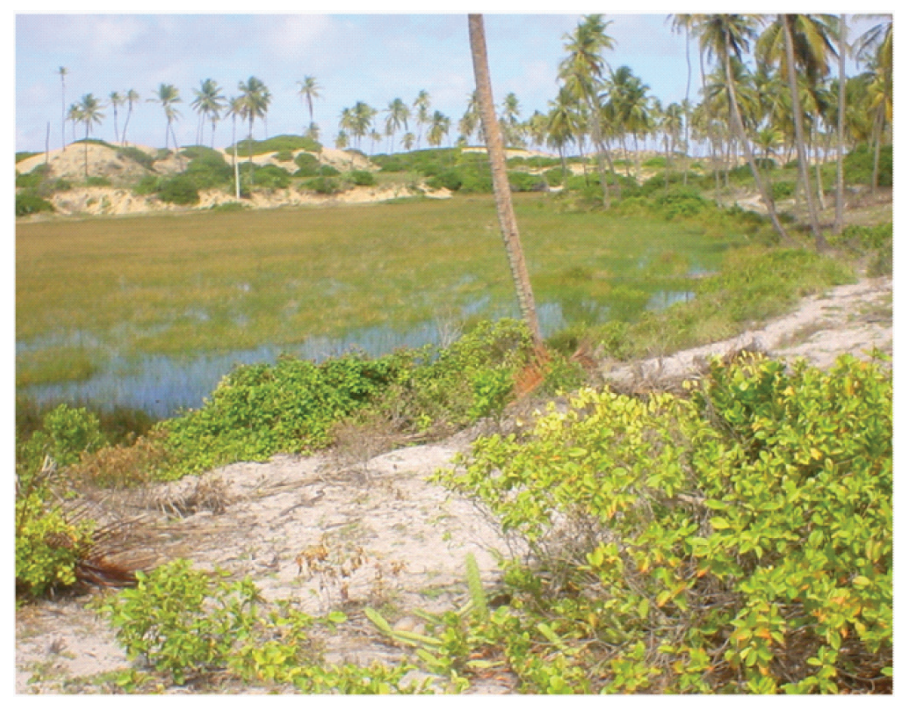

Figura 11. Zona úmida em declive por exudação da água subterrânea.

Figure 11. Slope wetlands groundwater-fed.

Foto: Soares 01/2008.

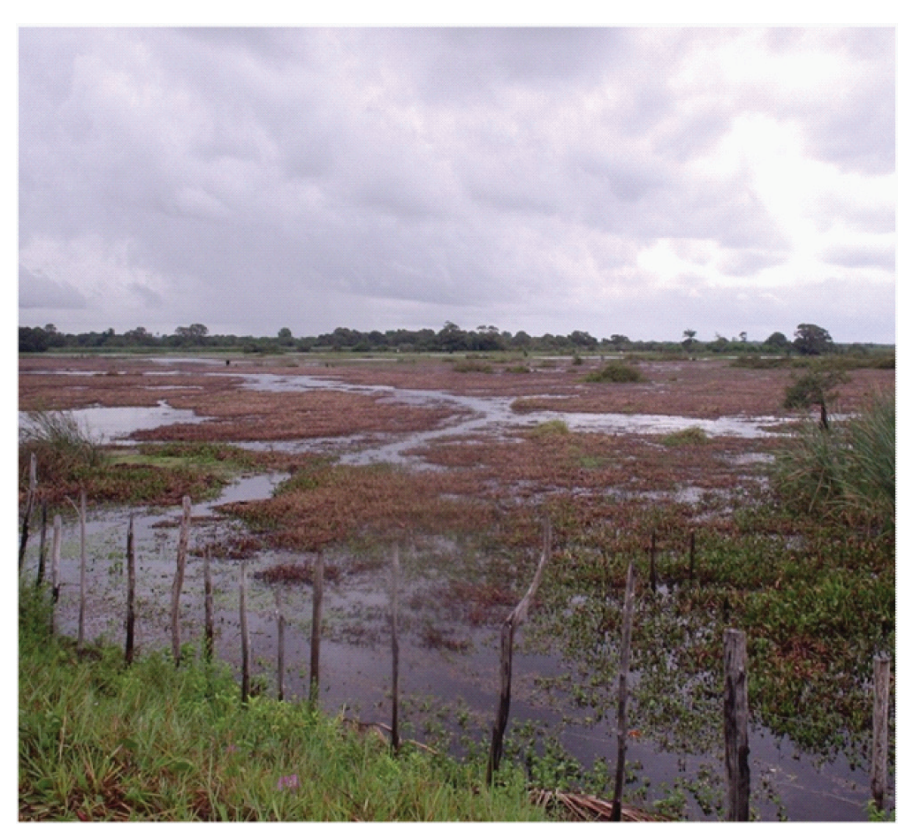

Figura 12. Zona úmida fluvial na planície de inundação. Figure 12. Fluvial wetland on inundation plain.

Foto: Soares 05/2007.

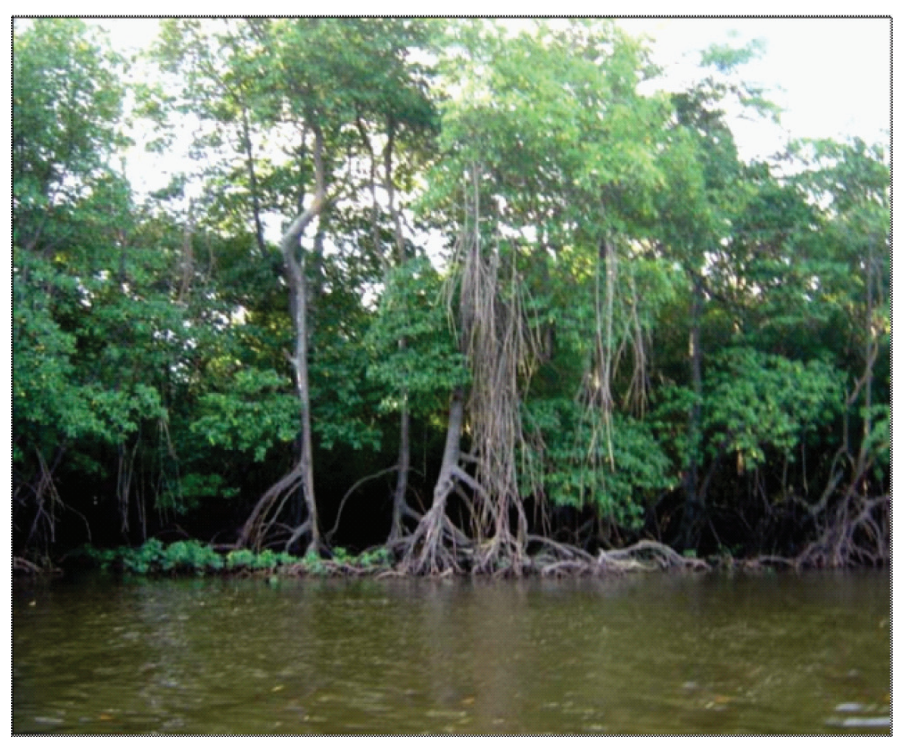

Figura 13. Zona úmida em franja mareal na desembocadura do rio Itapicuru.

Figure 13. Mareal fringe wetland on Itapicuru river mouth. Foto: Esquivel 01/2006. 


\section{PARÂMETROS HIDROGEOMORFOLÓGICOS DAS ZONAS ÚMIDAS NA PLANÍCIE COSTEIRA DO RIO ITAPICURU E OS SERVIÇOS DO ECOSSISTEMA}

A ausência de um mapa de uso do solo detalhado para a área de estudo impediu uma aplicação mais quantitativa do esquema de Sutter et al. (1999). Apesar disto foi possível avaliar a significância dos serviços do ecossistema aplicando alguns dos parâmetros definidos pelos referidos autores para a área de estudos. Cujos resultados são apresentados na Tabela 3. Esta tabela mostra que as zonas úmidas na planície do rio Itapicuru desempenham importantes serviços para a região discutida, uma vez que quase todos os parâmetros apresentaram uma significância alta.

Alguns dos aspectos que foram considerados na avaliação da significância dos serviços das zonas úmidas identificadas são discutidos a seguir:

\section{Proximidade das fontes não pontuais de poluição}

Dado mais de $20 \%$ do perímetro das zonas úmidas na planície costeira do rio Itapicuru ser ocupado por agricultura ou outras formas de uso do solo, a proximidade de fontes de poluição é classificada como alta em todas as classes de zonas úmidas estudadas. Este é um parâmetro que considera o uso do solo predominante na adjacência da zona úmida para avaliar suas condiçôes na limpeza não pontual de águas poluídas e de limpeza das águas de inundaçôes.

\section{Proximidade de corpos d'água}

Este parâmetro permite avaliar a significância da zona úmida em promover a limpeza não pontual de águas poluídas. Depende da proximidade de corpos d'água das zonas úmidas. Este parâmetro é classificado como alto dado as zonas úmidas estarem associadas com a planície costeira do rio Itapicuru.

Tabela 3. Significância dos serviços desempenhados pelas classes de zonas úmidas na planície costeira do rio Itapicuru.

Table 3. Significancy of services of coastal wetlands hydrogeomorphic class on Itapicuru river.

\begin{tabular}{|c|c|c|c|c|c|}
\hline Parâmetro & Serviços de zonas úmidas & Zu em declive & $\mathrm{Zu}$ depressional & Zu fluvial & $\mathrm{Zu}$ franja mareal \\
\hline $\begin{array}{c}\text { Proximidade das fontes de polu- } \\
\text { içáa }\end{array}$ & $\begin{array}{c}\text { Manutenção da qualidade das } \\
\text { águas }\end{array}$ & A & A & A & A \\
\hline Proximidade de corpos d'água & $\begin{array}{c}\text { Manutenção da qualidade das } \\
\text { águas }\end{array}$ & B & A & A & A \\
\hline Tipo de vegetação & $\begin{array}{l}\text { Manutenção da qualidade das } \\
\text { águas e disponibilidade de habitat }\end{array}$ & M & $\mathrm{A} / \mathrm{M}$ & B & $\mathrm{A} / \mathrm{M}$ \\
\hline Solos & $\begin{array}{c}\text { Manutenção da qualidade das } \\
\text { águas }\end{array}$ & M & A & M & A \\
\hline Duração da inundação & $\begin{array}{l}\text { Manutenção da qualidade das } \\
\text { águas e hidrológicos }\end{array}$ & A & A & A & A \\
\hline $\begin{array}{l}\text { Largura perpendicular da zona } \\
\text { úmida para o canal }\end{array}$ & $\begin{array}{l}\text { Manutenção da qualidade das } \\
\text { águas e hidrológicos }\end{array}$ & A & A & A & A \\
\hline Tamanho da zona úmida & Hidrológicos & A & A & A & A \\
\hline Geomorfologia & Hidrológicos & M & A & B & A \\
\hline Posição na bacia & Hidrológicos & A & A & A & A \\
\hline $\begin{array}{l}\text { Ocorrência de espécies ameaçada } \\
\text { ou ecossistema natural único }\end{array}$ & Disponibildade de habitat & A & A & A & A \\
\hline Justaposição da zona úmida & Disponibildade de habitat & A & A & A & A \\
\hline Habitat adjacente & Disponibildade de habitat & A & A & A & A \\
\hline Função da zona úmida como ilha & Disponibildade de habitat & A & A & A & A \\
\hline $\begin{array}{l}\text { Tamanho do interior no complexo } \\
\text { de habitat }\end{array}$ & Disponibildade de habitat & A & A & A & A \\
\hline $\begin{array}{c}\text { Associação com a superfície de } \\
\text { água }\end{array}$ & Disponibildade de habitat & A & A & A & A \\
\hline $\begin{array}{l}\text { Heterogeneidade interna do } \\
\text { complexo de habitat }\end{array}$ & Disponibildade de habitat & A & A & A & A \\
\hline
\end{tabular}

$\mathrm{Zu}=$ zonas úmidas 
Tipos de vegetação

Os tipos de vegetação de zonas úmidas são importantes tanto como fonte de limpeza náo pontual de poluição pelo escoamento superficial, quanto como de limpeza das águas das inundaçóes pelos canais de drenagem. A vegetação herbácea influencia tanto a classe em declive quanto as depressionais ou franjas mareais, localizadas na planície costeira do rio Itapicuru, sendo nestas duas últimas encontradas em associação às espécies arbóreas, categorizando desta forma, este parâmetro como alto.Também durante o serviço de disponibilidade de habitat estes tipos de vegetação influenciam o habitat interno para espécies terrestres e o habitat para anfíbios e invertebrados aquáticos nestas classes. Este parâmetro é classificado como baixo durante o desempenho dos serviços citados acima pela classe fluvial, pois nessa classe, gramíneas exóticas dominam a vegetação atualmente.

\section{Solos}

Nas classes de zonas úmidas depressionais e franja mareal, localizadas na planície costeira do rio Itapicuru os solos frequentemente inundados com muita matéria orgânica caracterizam a alta significância no desempenho da limpeza da água da inundação.

\section{Duração da inundação e largura perpendicular da zona úmida} para o canal

As classes de zonas úmidas localizadas na planície costeira do rio Itapicuru são inundadas por períodos variáveis, como a classe fluvial, ou são inundadas permanentemente. Quanto maior o período de inundação, mais favoráveis são as condiçôes funcionais de limpeza das águas de inundação, durante a manutenção das qualidades das águas; e de armazenamento de águas de inundação, durante o desempenho de serviços hidrológicos. Outro parâmetro que influencia o desempenho de serviços do ecossistema é a largura perpendicular da zona úmida em relação aos canais principais. Quanto maior esta largura, mais favoráveis é para às condiçôes de limpeza das águas.

\section{Tamanho e geomorfologia da zona úmida}

A área ocupada pelas zonas úmidas na planície costeira condiciona tanto o seu desempenho funcional na manutenção da qualidade das águas, quanto dos serviços hidrológicos, devido ao armazenamento de água na superfície. Quanto maior for a área das zonas úmidas maior será a significância destes serviços. Enquanto nas zonas úmidas depressionais, com geomorfologia em bacia, este parâmetro é alto, na classe fluvial este parâmetro é considerado baixo, pois esta atua como área para o espraiamento da inundação com capacidade de retenção dependente mais da infiltração da água do que do armazenamento em áreas com contornos fechados.

\section{Posiçẫo da zona úmida}

A posição da zona úmida em relação a um canal é outro parâmetro importante para a avaliação dos serviços dos ecossistemas. Quando a zona úmida está próxima a um canal de terceira ordem ou maior, como é o caso da planície costeira do rio Itapicuru, este parâmetro é considerado alto no que diz respeito à significância no armazenamento das águas da inundação durante o desempenho de serviços hidrológicos.
Ocorrência de espécies ameaçadas ou ecossistema natural único

A ocorrência de espécies ameaçadas e a presença de um ecossistema natural único (Dominguez et al., 1996) são parâmetros que condicionam como alta a disponibilidade de habitat pelas zonas úmidas da planície costeira do rio Itapicuru, no litoral Norte do estado da Bahia.

\section{Justaposição de zonas úmidas}

A justaposição das classes de zonas úmidas na planície costeira do rio Itapicuru, interligadas num complexo com áreas onde mais de $50 \%$ são bordejadas por outras classes de zonas úmidas, caracterizam este parâmetro como alto no fornecimento de habitat para espécies que utilizam as zonas úmidas.

\section{Habitat adjacente}

Para as zonas úmidas da planície costeira do rio Itapicuru o parâmetro habitats adjacentes é considerado alto, porque mais de 30 ha do complexo de zonas úmidas é circundado por ecossistemas naturais, como a Mata Atlântica, disponibilizando habitat para espécies terrestres e para anfíbios e invertebrados aquáticos. A presença de canais cortando as zonas úmidas é favorável também para habitat de peixes.

\section{Função da zona úmida como ilha}

A ocorrência do complexo de zonas úmidas na planície costeira do rio Itapicuru de forma isolada, resulta na atribuição de um valor alto para o parâmetro 'função da zona úmida como ilha' pela elevada influência na condição funcional da paisagem para habitat de espécies terrestres que utilizam as zonas úmidas.

\section{Tamanho do interior da zona úmida no complexo de habitat}

O tamanho do interior da zona úmida no complexo de habitat é um parâmetro também importante, pois quanto mais alto for o mesmo, maior a sua influência no fornecimento de habitat interno para espécies terrestres que utilizam as zonas úmidas. A disponibilidade de habitats proporcionados pelas zonas úmidas da planície costeira do rio Itapicuru este parâmetro é considerada alta, uma vez que mais de 30 ha do complexo das zonas úmidas é circundado por ecossistemas naturais, como a Mata Atlântica.

\section{Associação com a superfície de água}

Por as zonas úmidas classificadas serem associadas às superfícies de água, o rio Itapicuru, espécies terrestres que utilizam as zonas úmidas são favorecidas nesta região.

\section{Heterogeneidade interna do complexo de habitat}

No complexo de zonas úmidas associadas a planície costeira do rio Itapicuru, o número de tipos de vegetação favorece sua heterogeneidade interna e, portanto, aumenta asignificância na disponibilidade de habitat interno para espécies terrestres que utilizam as zonas úmidas.

\section{RISCO POTENCIAL DE PERDA DOS SERVIÇOS DESEMPENHADOS POR ZONAS ÚMIDAS}

O risco potencial de perda dos serviços para a paisagem onde as classes de zonas úmidas estáo inseridas avalia a significância delas em relação ao uso do solo e características da água na paisagem onde o serviço é desempenhado, para 
determinar o risco para a integridade da zona costeira.

Em todas as classes de zonas úmidas o tipo de cobertura vegetal é o fator determinante para que dois parâmetros sejam considerados na avaliação do risco de perda da zona úmida: a dificuldade de reposição da vegetaçáo e o uso do solo.

$\mathrm{O}$ risco de perda da zona úmida em declive por exudação da água subterrânea é muito influenciado pelo tipo de uso do solo nos terraços arenosos e pela extração de areia. $\mathrm{O}$ risco potencial de perda das zonas úmidas depressionais é relacionado à vulnerabilidade destas a subtração de água subterrânea e à contaminação do lençol freático.

Para as zonas úmidas depressionais, associadas a vales existe também uma maior vulnerabilidade a aterros, devido a presença de terrenos elevados.

O risco de perda dos serviços prestados pelas classes de zonas úmidas fluvial e franja mareal é altamente influenciado por suas vulnerabilidades à poluição e às intervenções que visam a regulação do rio.

Resumindo, o risco potencial de perda dos serviços de todas as zonas úmidas na área de estudo foi classificado como alto. Para as classes com cobertura da vegetação de porte arbóreo este risco de perda tem grande relevante principalmente pela dificuldade de reposição deste tipo de vegetação.

\section{CONCLUSÓES}

Neste trabalho as zonas úmidas da planície costeira do rio Itapicuru foram classificadas. Esta abordagem permitiu também avaliar parâmetros hidrogeomorfológicos importantes para o conhecimento dos serviços do ecossistema. Este tipo de investigação tem aplicabilidade, pois oferece informaçóes qualitativas do que pode ser feito nas zonas úmidas considerando seus principais controles ambientais e significância ecológica.

A classificação proposta se aplicada adequadamente é útil por diversas razões:

1. é simples, para zonas úmidas depressionais os critérios (conectividade com corpos d'água) e os dois tipos (aberta e fechada) priorizam a adição de parâmetros descritivos;

2. onomedeumazonaúmidatransmite consigoocontexto hidrogeomorfológico (e.g. o termo 'depressional com alimentação da água subterrânea', carrega em si a noção de uma depressão rasa, permanente, mantida pela exudação da água subterrânea);

3. os diferentes serviços dos ecossistemas de zonas úmidas podem ser claramente separados em um nível primário - e.g. depressional vs. fluvial;

4. a hidrogeomorfologia inerente à classe de zona úmida pode ser usada como requisito para uma adequada reabilitação futura;

5. a distribuição dos serviços nas classes dos ecossistemas de zonas úmidas mostra como a avaliação hidrogeomorfológica pode discriminar lugares ao longo de um gradiente ecológico.

\section{AGRADECIMENTOS}

Agradecemos a grande contribuição dos revisores do artigo, do Soledade Filho para a logística das expediçóes na Mata Paludosa, financeira da Universidade Federal da Bahia (UFBA) e da Coordenação de Aperfeiçoamento de Pessoal de Nível Superior (CAPES).

\section{BIBLIOGRAFIA}

Brinson, M.M. (1993) - A Hydrogeomorphic Classification for Wetlands. 79p., U.S. Army Corps of Engineers, Waterways Experiment Station, Wetlands Research Program Technical Report WRP-DE-4, Washington, DC, USA. http://el.erdc.usace.army.mil/wetlands/pdfs/ wrpde4.pdf

Centro de Estatística e Informação (CEI) (1994) - Informaçôes Básicas dos Municipios Baianos, Litoral Norte. volume 6, 440p., Salvador, BA, Brasil. ISBN 8571170150.

Clausen, J.C.; Ortega, I.M.; Glaude, C.M.; Relyea, R.A.; Garay, G.; Guineo, O. (2006) - Classification of Wetlands in a Patagonian National Park, Chile. Wetlands 26(1):217-229. doi: 10.1672/0277-5212(2006)26\%5b2 17:COWIAP\% $5 \mathrm{~d} 2.0 . \mathrm{CO} ; 2$

Cole, C.A. (2006) - HGM and wetland functional assessment: Six degrees of separation from the data? Ecological Indicators, 6(1):485-493. DOI: 10.1016/j. ecolind.2005.06.004

Cowardin, L.M.; Carter, V.; Golet, F.C.; LaRoe, E.T. (1979) - Classification of wetlands and deepwater habitats of the United States. U.S. Department of the Interior, Fish and Wildlife Service, Washington, DC., U.S.A. Disponível em http://www.npwrc.usgs.gov/resource/wetlands/classwet/ index.htm

CPRM (1982) - Lima, R.C.C.; Costa, I.V.G.; Silva, I.F.; Rocha, A.J.D. (1982) - Projeto Turfa na faixa costeira Babia-Sergipe. Relatório Integrado. 129p., CPRM Serviço Geológico do Brasil, Ministério das Minas e Energia, Departamento Nacional da Produção Mineral, Salvador, BA, Brasil.

Dalton, H.C. (1999) - Terrenos Inundáveis ("Wetlands") da Zona Costeira do Brasil: Herança Geológica e Alteraçôes por Mudanças Regionais e Globais.VII Congresso da ABEQUA, Porto Seguro, BA, Brasil.

Diegues, A.C. (1990) - Inventário de zonas úmidas do Brasil: versáo preliminar. 450p., Programa de Pesquisa e Conservação de Áreas Úmidas no Brasil, PRP, USP, São Paulo, SP, Brasil.

Dominguez, J.M.L.; Bittencourt, A.C.S.P.; Martin, L. (1990) - Geologia do Quaternário costeiro de Pernambuco. Revista Brasileira de Geociências (ISSN: 2177-4382), 20(1-4):208-215, São Paulo, SP, Brasil.

Dominguez, J.M.L.; Leão, Z.M.A.N.; Lyrio, R.S. (1996) - Litoral Norte do Estado da Bahia: evolução costeira e problemas ambientais. Roteiro da Excursão E4 do XXXIX Congresso Brasileiro de Geologia, 32p. Salvador, BA, Brasil.

Ehrenfeld, J.G. (2000) - Evaluating wetlands within an urban context. Ecological Engineering, 15(3-4):253-265. DOI: $10.1016 / S 0925-8574(00) 00080-\mathrm{X}$

Esquivel,M.S.(2006) - Quaternário costeiro do município de Conde: implicaçôes para a gestão ambiental. 113p., Dissertação de Mestrado, Universidade Federal da Bahia, Salvador, BA, Brasil. Não publicado.

Ewart-Smith, J.L.; Ollis, D.J.; Day, J.A.; Malan, H.L. (2006) - National Wetland Inventory: Development of a Wetland 
Classification System for South Africa. Water Research Commission, Report No.KV 174/06, Pretoria, South Africa. ISBN: 1-77005-429-4

Finlayson, C.M.; Begg, G.W.; Howes, J.; Davies, J.; Tagi, K.; Lowry, J. (2002) - A Manual for an Inventory of Asian Wetlands: Version 1.0. Wetlands International Global Series 10, Kuala Lumpur, Malaysia. ISBN: 9058820106.

Franklin, S. B.; Kupfer, J. A.; Pezeshki, R.; Gentry, R.; Smith, R.D. (2008) - Efficacy of the hydrogeomorphic model (HGM): A case study from western Tennessee. Ecological Indicators, 9:267-283. 10.1016/j.ecolind.2008.05.004.

Gilvear, D.J.; McInnes, R.J. (1994) - Wetland Hydrological Vulnerability and the Use of Classification Procedures: a Scottish CaseStudy. JournalofEnvironmentalManagement, 42(4):403-414. DOI: 10.1006/jema.1994.1080

Ivanauskas, N.M.; Rodrigues, R.R.; Nave, A G. (1997) Aspectos ecológicos de um trecho de floresta de brejo em Itatinga, SP: florística, fitossociologia e seletividade de espécies. Revista Brasileira de Botânica (ISSN 01008404), 20(2):139-153, São Paulo, SP, Brasil.

Leão, Z.M.A.N.; Dominguez, J.M.L .(2000) - Tropical coast of Brazil. Marine Pollution Bulletin, 41(1-6):112- 122. DOI: 10.1016/S0025-326X(00)00105-3.

Lugo, A.E.; Snedaker, S.C. (1974) - The Ecology of Mangroves. Annual Review of Ecology and Systematics, 5:39-64. DOI: 10.1146/annurev.es.05.110174.000351

Maltby, E. (2004) -Integration of Europe wetland research in sustainablemanagement of the watercycle. General Presentation of $1^{\text {a }}$ Conferência do Eurowet Project, Apresentação em PowerPoint, 36 slides. Disponível em http://eurowet. brgm.fr/Documents/conference/présentations_2809/ EUROWET_INTRO_280904.pdf

Martin, G.; Fitzsimons, V.; Duncan, W.; Bauer, I.; Harris; L., Habron, D.; McBride, A.; Johnstonova, A. (2007) - WFD66: Wetland Hidrogeomorphic Classification for Scotland. 94p., Sniffer - Scotland \& Northern Ireland Forum for Environmental Research, Edinburgh, U.K. Disponível em http://www.sniffer.org.uk/Webcontrol/ Secure/ClientSpecific/ResourceManagement/ UploadedFiles/WFD66 Final Report.pdf

Martin, L.; Bittencourt, A.C.S.P.; Vilas Boas, G.S.; Flexor, J.M. (1980) - Mapa Geológico do Quaternário Costeiro do Estado da Bahia, Texto Explicativo. 60p., Secretária de Minas e Energia / Coordenação de Produção Mineral, Salvador, BA, Brasil.

MEA (2005) - Ecosystems and Human Well-being: Wetlands and Water. Synthesis. 68p., MEA - Millennium Ecosystem Assessment, Word Resources Institute, Washington, D.C., U.S.A. ISBN: 1569735972 Disponível em http://www. maweb.org/documents/document.358.aspx.pdf

Merkey, D.H. (2006) - Characterization of Wetland Hydrodynamics Using HGM and Sub classification Methods in Southeastern Michigan, USA. Wetlands, 26(2):358-367. DOI: 10.1672/0277-5212(2006)26\%5 b358:COWHUH\%5d2.0.CO;2

NWWG (1997) - Warner, B.G.; Rubec, C.D.A. (eds.) (2007) - National Wetlands Working Group - The Canadian Wetland Classification System. Second Edition, 68p., NWWG - National Wetlands Working Group, Wetlands Research Centre, University of Waterloo, Waterloo, Ontario, Canadá. ISBN: 0662258576. Disponível em http://www.gret-perg.ulaval.ca/fileadmin/ fichiers/fichiersGRET/pdf/Doc_generale/Wetlands.pdf

Pasternack, G.B.; Hilgartner, W.B.; Brush, G.S. (2000) Biogeomorphology of an Upper Chesapeake Bay River-
Mouth Tidal Freshwater Marsh. Wetlands, 20(3):520537. doi: 10.1672/0277-5212(2000)020<0520:BOAU $\mathrm{CB}>2.0 . \mathrm{CO} ; 2$

Peck, D. (1999) - Classification system for wetland type. In: Strategic framework for the list of wetlands of international importance: Key documents of the Ramsar Conventions, 7th Meeting of the conference of the contracting parties to the convention on wetlands, San Jose, Costa Rica.

Shafer, D.J.; Roberts, T.H.; Peterson, M.S.; Schmid, K. (2007) - A Regional Guidebook for Applying the Hydrogeomorphic Approach to Assessing the Functions of Tidal Fringe Wetlands Along the Mississippi and Alabama Gulf Coast. Ecosystem Management and Restoration Research Program, Report ERDC/EL TR-07-2, 76p. + anexos, U.S. Army Engineer Research and Development Center, Vicksburg, MS, U.S.A. Disponível em http://el.erdc.usace.army.mil/elpubs/pdf/ trel07-2.pdf

Smith, D.R.; Ammann, A.; Bartoldus, C.; Brinson, M.M. (1995) - An Approach for Assessing Wetland Functions Using Hydrogeomorphic Classification, Reference Wetlands, and Functional Indices. 71p. + anexos, US Army Corps of Engineers. Waterways Experiment Station. Wetlands Research Program Technical Report WRP-DE-9, Vicksburg, MS, U.S.A. Disponível em http://el.erdc. usace.army.mil/wetlands/pdfs/wrpde9.pdf

Suguio, K.; Martin, L.; Bittencourt, A.C.S.P.; Dominguez, J.M.L.; Flexor, J.; Azevedo, A.E.G. (1985) - Flutuaçóes do nível relativo do mar durante o quaternário superior ao longo do litoral Brasileiro e suas implicaçôes na sedimentação costeira. Revista Brasileira de Geociências (ISSN: 2177-4382), 15(4):273-286, São Paulo, SP, Brasil.

Sutter, L.A.; Stanfill, J.B.; Haupt, D.M.; Bruce, C.; Wuenscher, J.E. (1999) - NC-CREWS: North Carolina Coastal Region Evaluation of Wetland Significance. A report of the strategic plan for improving coastal management in North Carolina. 111p., North Carolina Division of Coastal Management, Department of Environment and Natural Resources. Raleigh, NC. Disponível em http://dcm2.enr.state.nc.us/ wetlands/NCCREWSDOC.pdf

UNESCO (1998) - Wetlands of The Humid Tropics. Water - Related Issues and Problems of the Humid Tropics and Other Warm Humid Regions. 52p., UNESCO, Division of Water Sciences, Humid Tropics Programme Series N ${ }^{\circ}$ 12, Paris, França. Disponível em http://unesdoc.unesco. org/images/0011/001160/116084eo.pdf

Wardrop, D. H.; Kentula, M.E. Jensen; S.F.,Stevens Jr.; D.L., Hychka, K.C.; Brooks, R.P. (2007) - Assessment of Wetlands in the Upper Juniata Watersherd in Pennsylvania, USA Using the Hydrogeomorphic Approach. Wetlands, 27(3):432-445. ISSN: 1943-6246 (electronic version) doi: http://dx.doi.org/10.1672/02775212(2007)27[432:AOWITU]2.0.CO;2

Whigham, D.F.; Jacobs, A.D.; Weller, D.E.; Jordan, T.E.; Kentula, M.E.; Jensen, S.F.; Stevens, D.L. (2007) Combining HGM and EMAP Procedures to Assess Wetlands at the Watershed Scale - Status of Flats and Non-Tidal Riverine Wetlands in the Nanticoke River Watershed, Delaware And Maryland (USA). Wetlands (ISSN: 1943-6246), 27(3):462-478. ISSN: 1943-6246

Whittecar, G.R.; Daniels, W.L. (1999) - Use of hydrogeomorphic concepts to design created wetlands in southeastern Virginia. Geomorphology,31 (3-4):355-371. DOI: $10.1016 /$ S0169-555X(99)00081-1. 